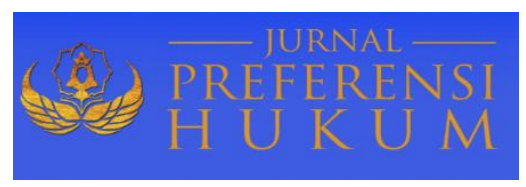

Jurnal Preferensi Hukum | ISSN: XXXX | E-ISSN: XXXX

Vol. 1 No. 1 - Juli 2020 hal. 46-51| Available online at https://www.ejournal.warmadewa.ac.id/index.php/juprehum

\title{
PROSES PENYITAAN BARANG BUKTI DALAM TINDAK PIDANA NARKOTIKA
}

\author{
I Kadek Sudikma, I Ketut Sukadana, I Nyoman Gede Sugiartha \\ Fakultas Hukum Universitas Warmadewa, Denpasar - Bali, Indonesia
}

\begin{abstract}
Abstrak
Kepolisian adalah lembaga pemerintah yang memiliki kewenangan untuk melakukan penyitaan, penyitaan yang dilakukan harus memenuhi unsur tindak pidana. Salah satu contoh penyitaan yang dilakukan oleh Kepolisian adalah penyitaan yang dilakukan dalam hal penyalahgunaan Narkotika. Tujuan dari penelitian ini adalah untuk mendeskripsikan pengaturan hukum pidana terhadap kejahatan narkotika dan untuk mengetahui wewenang penyidik dalam melakukan penyitaan barang bukti narkotika dan proses penyitaan barang bukti narkotika. Metode yang digunakan dalam penelitian ini adalah normatif dengan pendekatan perundang-undangan yang relevan terhadap masalah yang dikaji. Sumber bahan hukum yang digunakan adalah studi pustaka atau library research. Setelah bahanbahan hukum terkumpul, kemudian dianalisis secara kualitatif. Hasil penelitian ini menunjukkan bahwa penyitaan barang bukti adalah tahapan yang dilakukan sangat menetukan adanya tindak pidana atau tidak. Jika barang bukti untuk menetukan adanya tindak pidana sangat tepat maka pembuktian itu bisa dipakai untuk mendukung alat bukti lainya. Proses pelaksanaan penyitaan barang bukti tindak pidana narkotika dapat dilakukan dalam 4 (empat) macam bentuk penyitaan, yaitu: Penyitaan biasa, Penyitaan dalam keadaan mendesak, Penyitaan tertangkap tangan, Penyitaan Surat atau tulisan lain.
\end{abstract}

Kata Kunci: Kepolisian; Penyitaan; Narkotika; Barang Bukti; Tindak Pidana

\begin{abstract}
The police force is a government agency that has the authority to conduct foreclosures. Foreclosures that are carried out must meet elements of a criminal offense. One example of confiscation carried out by the Police is confiscation carried out in the case of abuse of Narcotics. The purpose of this study is to describe the regulation of criminal law against narcotics crimes and to determine the authority of investigators in confiscating narcotics evidence and the process of confiscating narcotics evidence. The method used in this study is normative with a legislative approach that is relevant to the problem under study. The source of legal material used is library research or library research. After the legal materials are collected, they are analyzed qualitatively. The results of this study indicate that confiscation of evidence is a stage that is carried out is very determining the existence of a criminal act or not. If the evidence to determine the existence of a crime is very appropriate, then the evidence can be used to support other evidence. The process of confiscating evidence of narcotics crime can be carried out in four types of foreclosure, namely: Ordinary confiscation, Confiscation in a state of emergency, Confiscation of caught hands, Confiscation of Letters or other writings.
\end{abstract}

Keywords: Police; Foreclosure; Narcotics; Evidence; Criminal Acts

\section{PENDAHULUAN}

Narkotika adalah obat-obatan tertentu yang berguna dalam hal medis. Meski mengandung zat-zat yang berbahaya namun juga memiliki manfaat dibidang medis meskipun tetap memiliki efek tersendiri, (Armono, 2014). Obat-obatan dimaksud adalah sebagai penyembuh suatu penyakit ataupun pencegahan terhadap suatu penyakit, namun apabila banyak disalahgunakan atau dengan nama lain peruntukkannya tidak sesuai dengan medis (aturan dikedokteran) maka hal tersebut sangat merugikan seseorang maupun masyarakat pada umumnya. Apabila narkotika disalahgunakan maka akan berakibat fatal bagi penggunanya. Zat yang terkandung didalam Narkotika itu sangat banyak kegunaanya apabila digunakan 
dengan aturan dokter, namun pada kenyataanya di dunia khususnya di Indonesia ini sangat merugikan kehidupan bangsa dan sangat merusak nilai-nilai budaya bangsa ini dan sangat erat kaitannya melemahkan kecerdasan bangsa hingga melemahkan ketahanan Negara ini.

Pengertian Penyalahgunaan narkotika adalah pemakaian terus menerus dan berlebihan tanpa resep dokter yang tidak dimaksudkan untuk pengobatan, namun untuk kesenangan dalam pengaruh obatnya yang berlebihan dan berlangsung terus menerus, hingga mengakibatkan kerusakan mental, sosial dan gangguan kesehatan yang berkepanjangan sudah tentu Narkotika sangat buruk sekali akibatnya jika disalahgunakan.

Kita bisa lihat di Indonesia narkotika sudah menyasar para remaja yang notabene adalah orang-orang yang akan meneruskan cita-cita bangsa ini namun dirusak oleh tangan-tangan jahil orang jahat yang ingin menghacurkan Indonesia dengan cara menghancurkan generasi muda Indonesia. Hal ini jelas dikatakan oleh Eleanora (2011) dalam penelitiannya bahwa kasus penyalahgunaan narkoba di Indonesia mengalami peningkatan sangat tajam. Hasil penelitian Veronica, Langi, \& Joseph (2018) juga menunjukkan bahwa sekitar 2,5\% remaja dalam penelitian yang dilakukan terhadap 19882 remaja usia 15-24 sebagai populasi penelitian memiliki sejarah penyalahgunaan narkoba. Pernyataan ini didukung oleh hasil penelitian dari Purwatiningsih (2016) bahwa pengguna atau pihak yang terlibat kebanyakan adalah kelompok usia muda dan kebanyakan yang menyalahgunakan NAPZA adalah laki-laki, (Nur'artavia, 2017). Adapun faktorfaktor yang melatarbelakangi hal tersebut adalah faktor pengetahuan, sikap (Jumaidah \& Rindu, 2017), keluarga dan lingkungan tempat tinggal, (Nurmaya, 2016).

Perlunya sanksi yang tegas dari pemerintah tanpa pandang bulu baik itu pengedar ataupun yang memproduksi, semua harus dijatuhi humuman yang maksimal, setimpal dengan perbuatan yang mereka lakukan yang membuat para pemuda bangsa ini menjadi kecanduan obat-obatan terlarang dan merusak masa depan generasi muda Indonesia. Adapun sanksi pidana yang sekarang ini diberlakukan di Indonesia masih jauh dari harapan, kurang efektif diakibatkan oleh adanya penjatuhan pidana yang tidak memberikan dampak atau deterrent effect terhadap pelaku (Asyharudddin, Badaru, \& Hidjaz, 2020) dan adanya tumpang tindih kepentingan membuat sanksi tidak diberlakukan secara maksimal. Masih banyaknya perdaran Narkotika di Indonesia bahkan di dalam lapas sendiri masih beredar dan bagi pengguna masih bisa menikati barang haram dimaksud dengan leluasa.

Penjatuhan sanksi pidana belum membuat efek jera baik bagi pemakai dan pengedar Narkotika, sanksi-sanksi yang ada masih bisa dimanipulasi dengan alasan harus segera direhabilatasi namun pada kenyataan banyak yang keluar dari pusat rehabilatasi narkoba masih menggunakan ataupun memakai barang haram dimaksud. Mudahnya mendapatkan narkoba menjadi alasan selama ini bagi pengguna untuk menggunakan obat-obatan tersebut dengan dalih bahwa mereka menggunakannya demi kepentingan pribadi. Padahal efek dari narkoba bukan hanya dirasakan olehnya sendiri namun seluruh keluarga juga akan menanggung akibatnya.

Para pelaku penyalahgunaan narkotika adalah para penjahat yang lupa bahwa mereka juga bagian dari korban terhadap ganasnya narkotika. Namun mereka tanpa peduli dengan aturan ataupun hak-haknya sendiri sebagai korban yang harusnya diperhatikan oleh Negara, dan pada saat yang bersamaan seolah- olah Negara membiarkan tanpa perduli nasib dari pengguna narkoba itu sendiri.

Kaidah Hukum itu seharusnya adalah salah satu sistem yang diperlukan demi mewujudkan keadilan bagi seluruh rakyat Indonesia, memberikan manfaat dan kepastian hukum itu sendiri sebagaimana yang diamanatkan didalam Undang-Undang Nomor 35 Tahun 2009 tentang Tindak Pidana Narkotika. Biasanya seseorang yang menyalah gunakan Narkotika di proses yang ujung-ujungnya di kenakan sanksi pidana, padahal hal tersebut bukan satu-satunya upaya yang bisa dilakukan bisa jadi di proses atau di rehabilitasi terlebih dahulu hingga orang dimaksud sembuh dari ketergantungan Narkotika agar tidak menimbulkan persoalan-persoalan yang baru.

Adapun penelitian terkait yang mengkaji hal serupa dengan penelitian sekarang ini telah dilakukan sebelumnya oleh beberapa peneliti, diantaranya adalah Amanda, Humaedi, \& Santoso (2017) dalam penelitiannya berjudul "Penyalahgunaan Narkoba di Kalangan Remaja". Hasil penelitian ini menunjukkan bahwa ada tiga upaya yang dilakukan untuk mengatasi permasalahan remaja tersebut yaitu: 1) pendekatan agama (religius); 2) pendekatan psikologis; dan 3) pendekatan sosial. Penelitian serupa juga dilakukan oleh 
Widodo (2018) yang berjudul "Kewenangan yang Dimiliki oleh Penyidik dalam Tindakan Menyuruh Berhenti Orang yang Di Curigai (Tinjauan Pasal 5 Huruf A, Angka 3 KUHAP)". Berdasarkan analisis, hasil penelitian ini menunjukkan bahwa penyidik bertindak untuk melakukan wewenang untuk menghentikan seseorang untuk berhenti dicurigai dan meminta dan juga untuk memeriksa identitas yang ditambahkan ke Pasal 5 Huruf E No. 3 Konstitusi hukum pidana. Berdasarkan latar belakang dan penelitian terdahulu di atas, penelitian ini bertujuan untuk mendeskripsikan pengaturan hukum pidana terhadap kejahatan narkotika dan untuk mengetahui wewenang penyidik dalam melakukan penyitaan barang bukti narkotika dan proses penyitaan barang bukti narkotika.

\section{METODE}

Metode yang digunakan dalam penelitian ini adalah metode yuridis normative. Menurut Soekanto \& Mamudji (2001), yuridis normatif yaitu penelitian hukum yang dilakukan dengan cara meneliti bahan pustaka atau data sekunder sebagai bahan dasar untuk diteliti dengan cara mengadakan penelusuran terhadap peraturan-peraturan dan literatur-literatur yang berkaitan dengan permasalahan yang diteliti. Pendekatan yang digunakan dalam penelitian ini adalah pendekatan perundang-undangan yang relevan dengan masalah yang dikaji. Sumber bahan hukum yang digunakan dalam penelitian ini adalah studi pustaka atau library research. Setelah bahan-bahan hukum terkumpul maka penelitian ini dianalisis secara kualitatif, yaitu dengan memilih bahan hukum serta kualitasnya yang dapat menjawab permasalahan yang ada.

\section{HASIL DAN PEMBAHASAN}

\section{Pengaturan Hukum Pidana Terhadap Kejahatan Narkotika}

Adapun penggolongan narkotika sebagaimana yang dirumuskan dalam pasal 6 Undang-undang Nomor 35 Tahun 2009 tentang Narkotika adalah sebagai berikut:

1. Narkotika golongan I

Ketentuan undang-undang narkotika golongan I adalah narkotika yang bertujuan atau dipergunakan dalam pengembangan ilmu pengetahuan dalam hal medis, tidak untuk digunakan dalam hal apapun yang memberikan dampak ketergantungan yang sangat tinggi.

2. Narkotika golongan II

Ketentuan undang-undang narkotika golongan II adalah narkotika yang digunakan dalam hal medis yang diperlukan sesuai kebutuhan dan dosis yang tepat untuk menyembuhkan ataupun digunakan sebagai terapi, dan ini adalah pilihan terakhir apabila tidak pilihan lagi, dan mempunyai resiko kertgantungan yang sangat tingi.

3. Narkotika golongan III

Ketentuan undang-undang narkotika golongan III adalah jenis golongan yang banyak untuk digunakan dalam dunia farmasi yang berkasiat sebagai alat penyembuh ataupun pengobatan serta dapat digunakan sebagai terapi ataupun diganakan sebagai penunjang bagi ilmu pengetahuan, serta mempunyai potensi ringan yang mengakibatkan ketergantungan.

Indonesia telah banyak meratifikasi atau mengkonvesi peraturan-peraturan International terkait dengan peredaran narkotika, tujuanya adalah sebagai aspek kepentingan nasional demi mendapatkan kepastian hukum dan mendapatkan keadilan demi menjaga kesetabilan Indonesia dalam penegakkan hukum peredaran gelap narkotika yang banyak melibatkan jaringan pengedar Narkoba international, yang kita tahu banyak sekali Narkotika yang di Impor dari Negara lain dan diperjula belikan di Indonesia. Maka dari itu demi kepentingan bangsa ini terkhusus kepentingan masyarakat Indonesia, mendapatkan manfaat dan kepastian dalam hal peraturan Peredaran Narkotika untuk kepentingan pengobatan dan sebgai ilmu pengetahuan supaya masyarakat mengerti bahaya dari narkotika dimaksud (Sunarso, 2004: 1).

Di Indonesia banyak sekali yang telah ditangkap dan dipidanakan baik itu warga Negara Indonesia mauapun warga Negara asing yang menyelundupkan Narkotika dengan berbagai cara, namun pada 
kenyataanya sanski pidana yang dikenakan bagi pelaku-pelaku tersebut masih jauh dari harapan yang mana dampak dari kerusakan penyalahgunaan narkotika sendiri lebih besar dan dapat menghancurkan sebuah Negara. Bisa kita lihat saat ini masih banyaknya peredaran Narkotika dan bahkan para pelaku/gembonggembong narkotika itu masih bisa mengendalikan dari balik jeruji tahanan dalam hal peredaran Narkotika.

Aturan yang mengatur terkait dengan narkotika telah diundangkan dan berlaku bagi seluruh rakyat Indonesia bahkan bagi Waga Negara Asing yang melakukan kejahatan dimaksud di Indonesa, namun kejahatan yang menyangkut narkotika masih jauh dari harapan Undang-undang. Banyaknya kasus penangkapan bandar-bandar, pabrik narkotika serta para pengedar yang mendapatkan sanski berat namun banyak para pelkau yang belum tertangkap masih tidak peduli dan tetap mengedarkan dan memperluas jaringannya (Kaligis, 2002: 260).

Ketentuan Tindak pidana Narkotika diatur dalam Undang-Undang Nomor 35 Tahun 2019 tentang Narkotika termuat dalam Bab XV pasal 111 sampai dengan Pasal 148. Adapun pasal-pasal yang sering digunakan penyidik dalam menjerat Penyalahgunaan Narkoba sebagai berikut:

1. Pecandu Narkotika (Pasal 1 angka 13 jo Pasal 54 jo Pasal 127 Undang-Undang Nomor 35 Tahun 2009 tentang Narkotika).

2. Penyalahgunaan Narkotika dalam Pasal 1 angka 15

3. Pengedar Narkotika, nama-nama keren sesuai dengan fungsi dan peranya masing-masing, yakni:

a. Pihak yang memproduksi Narkotika secara melawan hukum (Pasal 1 angka 3 jo Pasal 113);

b. Pihak yang Mengimpor Narkotika secara Melawan Hukum (Pasal 1 angka 4 jo Pasal 113);

c. Pihak yang mengekspor Narkotika secara melawan hukum (Pasal 1 angka 5 jo Pasal 113);

d. Pihak yang melakukan ekspedisi atau yang mengangkut Narkotika secara melawan hukum (Pasal 1 angka 9, 12 jo Pasal 115);

e. Pihak mengedarkan secara melawan hukum Narkotika dan Presikusor Narkotika (Pasal 1 angka 6 jo $111,112,129)$.

Penyelidikan adalah upaya penyidik untuk menggali suatu peristiwa kejahatan hingga menentukan dugaan adanya tindak pidana, dan dapatkah suatu peristiwa dimaksud dilanjutkan tindakan penyidikan atau tidak, sebagaimana yang di atur dalam Undang-undang. Dengan pengertian tersebut maka bisa disimpulkan bahwa tugas penyidik adalah menentukan ataupun menemukan suatu tindak pidana yang diduga dilakukan oleh seseorang yang mana penentuan peristiwa dimaksud di adili dan diputus bersalah oleh Hakim di Pengadilan sesuai dengan keyakinan Hakim itu sendiri dan dipidana sesuai perbuatannya yang dilakukan (Husein, 1991:56).

Adapun tugas pokok yang dilakukan oleh penyidik menurut ketentuan pasal 7 ayat 1 KUHAP antara lain sesuai dengan standar yang dilakukan olejh pihak kepolisian Republik Indonesia:

a. Menerima pengaduan dari seorang telah terjadinya suatu kejahatan

b. Melaksanakan olah tempat kejadian perkara

c. Memberhentikan seseorang yang diduga melakukan tindak kejahatan dan memeriksa tanda pengenalnya

d. Melakukan penangkapan, penahanan, penggeledahan, dan penyitaan

e. Memeriksa dan menyita alat bukti surat

f. Mengambil sidik jari dan memotret seorang

g. Memanggil orang untuk didengar dan diperiksa sebagai tersangka atau saksi

h. Mendatangkan orang ahli yang diperlukan dalam hubungannya dengan pemeriksaan perkara

i. Mengadakan penghentian penyidikan

j. Mengadakan tindakan lain yang menurut hukum bertanggung jawab 


\section{Penyitaan Barang Bukti dan Proses Penyitaan Barang Bukti Narkotika}

Penyitaan adalah tindakan hukum yang dilakukan oleh penyidik pada saat proses pemeriksaan dilakukan secara hukum atas suatu barang yang mana barang tersebut dicurigai sebagai barang bukti suatu tindak pidana dengan kekawatiran barang bukti dimaksud dimusnahkan dan mengaburkan suatu tidak pidana. Penyitaan bertujuan untuk membuat terang benderang suatu tindak kejahatan yang dilakukan dan sebagai alat bukti yang mendukung kejahatan yang dilakukan (Hartono, 2010:182).

Adanya laporan dari masyarakat tindakan penyidikan dimulai oleh penyidik demi menentukan apakah perbuatan tersebut masuk dalam kategori tindak pidana atau pelanggaran. Pemeriksaan suatu perkara yang dilakukan oleh penyidik baik itu berbentuk pengaduan, laporan ataupun temuan sendiri. Setelah berkas dinyatakan lengkap maka Penyidik melimpahkan ke Kejaksaan maka oleh penuntut umum dilimpahkan ke pengadilan untuk diproses. Dan selanjut pengadilan memproses serta mengadili sesuai dengan dakwaan yang dibuat oleh Penuntut Umum (Afiah, 1988:14).

Proses pemeriksaan dan menentukan apakah orang itu bersalah atau tidak hanya keyakinan hakim yang bisa memutuskan, harapan masyarakat Indonesia bagi aparat penegak hukum untuk tidak bernegoisasi dengan para pengedar dan pencandu Narkotika, harusnya hukuman yang seberat-beratnya diberikan karena efek dan dampak dari Narkotika itu merusak kehidupan berbangsa dan bernegara, menghacurkan generasi penerus bangsa ini.

Dari aturan tentang penyitaan yang diatur didalam peraturan perudang- udangan yang berlaku di Indonesia dapat diurut sesuai dengan urutannya sebagai berikut:

a. Penyitaan biasa

b. Penyitaan dalam keadaan perlu dan mendesak

c. Penyitaan dalam keadaan tertangkap tangan

d. Penyitaan tidak langsung

e. Penyitaan surat atau tulisan lain

Kewenangan penyitaan yang dimiliki oleh Penyidik hanya dapat dilakukan dengan Ijin Ketua pengadilan negeri setempat, tanpa itu penyidik tidak bisa menyita dengan sembarangan atau dengan kata lain penyitaan yang dilakukan tanpa ijin dari Ketua Pengadilan penyitaan tersebut tidak sah dan cacat hukum. Terkecuali dalam keadaan sangat perlu dan medesak yang mana dikawatirkan barang yang akan disita itu diyakini akan dimusnahkan atau dihilangkan maka penyidik berwenang melakukan penyitaan secara mendesak namun setelah itu penyidik melaporkan kepada Pengadilan Negeri Setempat dan diberikan ijin melakukan Penyitaan.

Proses penyitaan harus sesuai dengan aturan yang berlaku apabila aparat penegak hukum melakukan dengan melanggar aturan maka penyitaan tersebut adalah proses yang cacat hukum bahkan berakibat fatal yakni membebaskan tersangka dari dugaan tindak pidana yang dilakukan. Hal ini perlu kahati-hatian dan ketelitian para penyidik untuk melakukan penyitaan terhadap suatu barang baik barang bergerak maupun tidak bergerak yang diyakini adalah alat yang digunakan sebagai tindak kejahatan.

\section{KESIMPULAN}

Kewenangan yang dimiliki penyidik dalam melakukan penyitaan barang bukti Narkotika berdasarkan isi dari Pasal 1 butir 2 menentukan serangkaian tindakan penyidik dalam hal dan menurut cara yang diatur dalam undang-undang ini untuk mencari serta mengumpulkan bukti yang dengan bukti itu membuat terang tentang tindak pidana yang terjadi dan guna menemukan tersangkanya. Objek utama tindak pidana narkotika yang gampang sekali untuk disimpan, dibuang ataupun di selipkan pada sautu tempat tertentu hingga mudah untuk dihancurkan, maka penyidik cenderung menggunakan penyitaan dalam keadaan mendesak Pada tindak pidana narkotika, objek utama yang dapat menjadi barang bukti adalah narkotika yang dijelaskan pada Undang-undang Nomor 35 Tahun 2009 tentang Narkotika. Tindakan penyitaan yang dilakukan oleh pihak kepolisian dalam hal pemeriksaan barang bukti kejahatan Narkotika dapat dilakukan dalam 4 (empat) macam bentuk penyitaan, yaitu: a) Penyitaan biasa; b) Penyitaan dalam keadaan mendesak; 
c) Penyitaan tertangkap tangan; d) Penyitaan surat atau tulisan lain. Adapun saran yang dapat diberikan kepada aparat Kepolisian Republik Indonesia, dalam hal menyita barang hasil kejahatan penyalahgunaan Narkotika ataupun obat-obatan terlarang, penyidik Kepolisian perlu mengetahui dan mencari cara pelaku tindak pidana Narkotika untuk menyembunyikan atau memusnahkan barang bukti dan untuk warga bangsa Indonesia harus lebih berperan aktif dan tidak membantu suatu kejahatan tindak pidana Narkotika untuk meleyapkan ataupun menyimpan barang bukti kejahatan narkotika, dan kedepannya semoga semua aparat penegak hukum bersirnergi untuk mengatasi kajahatan peredaran Narkotika agar tidak ada lagi generasigenerasi pemuda bangsa yang terjerat dalam pusaran Narkotika.

\section{DAFTAR PUSTAKA}

Afiah, R. N. (1988). Barang Bukti Dalam Proses Pidana. Jakarta: Sinar Grafika.

Amanda, M. P., Humaedi, S., \& Santoso, M. B. (2017). Penyalahgunaan Narkoba di Kalangan Remaja (Adolescent Substance Abuse). Prosiding Penelitian Dan Pengabdian Kepada Masyarakat, 4(2). doi:10.24198/jppm.v4i2.14392

Armono, Y. W. (2014). Kegunaan Narkotika Dalam Dunia Medis. PROSEDING SEMINAR UNSA. Retrieved from https://ejournal.unsa.ac.id/index.php/prosedingunsa/article/view/88

Asyharudddin, M., Badaru, B., \& Hidjaz, M. K. (2020). Analisis Sanksi Pidana Terhadap Pelaku Tindak Pidana Narkotika. PLENO JURE, 9(1), 58-71. doi:10.37541/plenojure.v9i1.390

Eleanora, F. N. (2011). Bahaya Penyalahgunaan Narkoba Serta Usaha Pencegahan dan Penanggulangannya (Suatu Tinjauan Teoritis). Jurnal Hukum, 25(1), 439-452. Retrieved from http://jurnal.unissula.ac.id/index.php/jurnalhukum/article/view/203

Hartono. (2010). Penyidikan dan Penegakan Hukum Pidana Melalui Pendekatan Progresif. Jakarta: Sinar Grafika.

Husein, H. M. (1991). Penyidikan dan Penuntutan Dalam Proses Pidana. Jakarta: PT. Rineka Cipta.

Jumaidah \& Rindu. (2017). Perilaku Pencegahan Penyalahgunaan Narkoba pada Remaja di Wilayah Kecamatan Sukmajaya, Depok. Jurnal Ilmiah Kesehatan, 16(1), 4-13. doi:https://doi.org/10.33221/jikes.v16i03.284

Kaligis, O. C. (2002). Narkoba dan Peradilannya di Indonesia (Reformasi Hukum Pidana Melalui Perundangan dan Peradilan). Bandung: Alumni.

Nur'artavia, M. R. (2017). Karakteristik Pelajar Penyalahguna Napza dan Jenis Napza yang Digunakan di Kota Surabaya. The Indonesian Journal of Public Health, 12(1), 27. doi:10.20473/ijph.v12i1.2017.27-38

Nurmaya, A. (2016). Penyalahgunaan napza di kalangan remaja (studi kasus pada 2 Siswa di MAN 2 Kota Bima). Jurnal Psikologi Pendidikan Dan Konseling: Jurnal Kajian Psikologi Pendidikan Dan Bimbingan Konseling, 2(1), 26. doi:10.26858/jpkk.v2i1.2064

Purwatiningsih, S. (2016). Penyalahgunaan Narkoba di Indonesia. Populasi, 12(1). doi:10.22146/jp.12275

Soekanto, S., \& Mamudji, S. (2001). Penelitian Hukum Normatif (Suatu Tinjauan Singkat). Jakarta: Rajawali Pers.

Sunarso, S. (2004). Penegakkan Hukum Psikotropika dalam Kajian Sosiologi Hukum. Jakarta: Raja Grafindo Persada.

Veronica, R. N., Langi, F. L. F. G., \& Joseph, W. B. S. (2018). Prevalensi dan Determinan Penggunaan Narkotika dan Obat- Obatan Terlarang di Kalangan Remaja Indonesia; Analisis Data Survei Demografi dan Kesehatan Indonesia Tahun 2012. Jurnal Kesmas, 7(5), 1-10. Retrieved from https://ejournal.unsrat.ac.id/index.php/kesmas/article/view/22037

Widodo, M. T. (2018). Kewenangan yang Dimiliki oleh Penyidik dalam Tindakan Menyuruh Berhenti Orang yang Di Curigai (Tinjauan Pasal 5 Huruf A, Angka 3 KUHAP). Jurnal Ilmu Hukum Dan Sosial, 1(1), 211-219. Retrieved from http://ejurnal.untag-smd.ac.id/index.php/DD/article/view/4251 